\title{
DEVELOPMENT OF TRANSPORT INFRASTRUCTURE IN LATVIA, LITHUANIA AND POLAND WITH SUPPORT OF STRUCTURAL FUNDS
}

\author{
Maciej Stawicki ${ }^{1}, \mathrm{PhD}$ \\ ${ }^{1}$ Warsaw University of Life Sciences (WULS-SGGW)
}

\begin{abstract}
The main aim of the paper is to compare the investments in transport infrastructure with support of structural funds in Latvia, Lithuania and Poland. The specific objectives were: classification of projects connected with transport infrastructure development, calculation of the share of infrastructure projects in all EU funding and identification of types of beneficiaries. Desk research, review of literature and databases, statistical and descriptive methods were used. The material used was databases of projects implemented in the period 2007-2016 co-financed by EU structural funds in the programming period 2007-2013. Poland was the largest EU-funds for infrastructure absorber (30 billion EUR), and in Latvia and Lithuania the total values of all transport infrastructure supporting projects were very close to each other (1.7 billion EUR). The share of transport infrastructure funding among all EU co-financed projects was similar in all countries, although in Poland it was higher (31.2 \%) than in Lithuania (21.7\%) and Latvia (24.8 \%). Developing the Trans-European Transport Network (TEN-T) and rail infrastructure projects (i.a. Rail Baltica connecting Warsaw with Kaunas) were the two types of projects with highest share in all countries. In Lithuania and Poland, there was quite high funding for national, regional and local roads and highways reconstruction, while in Latvia investments in sea ports took the third place in total share of funding. Nearly all airports in the three countries benefited from the EU funds. The structure of beneficiaries was very diversified in Poland, while in Lithuania all infrastructure investments were highly institutionally concentrated.
\end{abstract}

Key words: transport infrastructure, EU structural funds, Latvia, Lithuania, Poland. JEL code: $018, \mathrm{R} 42$

\section{Introduction}

Structural funds are an instrument of European Union's regional and cohesion policy used to reduce regional differences (Bachtler J., Turok I., 2013). As part of equalizing the level of development and increasing cohesion of European countries, an important element is development of infrastructure, which has positive impact on private investment and employment (Pereira A. M., Andraz J. M., 2005) and is necessary impulse for economic development. Transport infrastructure is defined as all routes and fixed installations of the three modes of transport being routes and installations necessary for the circulation and safety of traffic (EC, 2006).

As there is lack of international comparative studies, the main aim of the paper is to identify and compare the amount of financing the development of transport infrastructure with support of structural funds (later in the text also called EU funds) in 3 selected countries: Latvia, Lithuania and Poland. The specific objectives were: classification of projects connected with transport infrastructure development, calculation of the share of infrastructure projects in all EU funding and present examples of implemented projects. Types of beneficiaries were identified - only in Lithuania and Poland because of data accessibility. Special attention was paid to the TEN-T network development and binding all three analysed countries.

Desk research (review of literature and databases, ordering, classification of projects), statistical methods (relative and absolute indicators), field observations and descriptive methods were used, the data were presented using tables and graphs elaborated with Excel software.

The material used was databases of projects implemented in the period 2007-2016 co-financed by EU structural funds in the programming period 2007-2013 downloaded from the national websites concerning EU funding in analysed countries (funduszeeuropejskie.2007-2013.gov.pl, 2018; esparama.It, esfondi.lv, 2017). The data were published by Ministry of Finance of the 
Republic of Latvia (MF), Ministry of Finance of the Republic of Lithuania (MF), Ministry of Investment and Economic Development of the Republic Poland (MIED) - later in the text the abbreviations will be used. During the analysis of Polish database, the author quite often came across many errors in beneficiaries' classification, sometimes the same entity was classified in two different ways. One can conclude that the Polish EU funds monitoring system allows incorrect classification and is not unequivocal for its users. Despite different structure of databases and differences in project descriptions, the project types were analysed and classified into the following groups: rail infrastructure, national roads, regional and local roads, the TEN-T routes, sea transport infrastructure, inland water transport infrastructure, airports, city transport, multimodal and other transport. In this way it was possible to compare the amount of funding for transport infrastructure in Latvia, Lithuania and Poland.

\section{Research results and discussion \\ 1. EU support for transport infrastructure}

Poland was the largest (about 96 billion EUR) EU funds absorber in the period 2007-2013, so, as a result, also the amount and value of projects investing in infrastructure was the highest, 17 times higher than in the two other analysed countries. Interestingly, the situation in Latvia and Lithuania was very similar - the total values of all transport infrastructure supporting projects were very close to each other (1.7 billion EUR) (Tab. 1).

Comparing relative indicators, it is clear that in relation to the country area in Poland the total value of transport projects was highest, but only 4 times higher than in Lithuania and Latvia. In relation to the population, Latvia invested most, Poland took second place and Lithuania the third with 587 thousand euro per capita.

Table 1

The main indicators concerning EU support for transport infrastructure (perspective 2007-2013)

\begin{tabular}{|l|c|c|c|c|c|}
\hline & $\begin{array}{c}\text { sum of EU } \\
\text { funding } \\
\text { [m. EUR] }\end{array}$ & $\begin{array}{c}\text { transport } \\
\text { infrastructure } \\
\text { funding [m. EUR] }\end{array}$ & $\begin{array}{c}\text { share of } \\
\text { transport } \\
\text { funding } \\
\text { [\%] }\end{array}$ & $\begin{array}{c}\text { transport } \\
\text { infrastructure } \\
\text { funding per sq. km } \\
\text { [thous. EUR] }\end{array}$ & $\begin{array}{c}\text { transport } \\
\text { infrastructure } \\
\text { funding per } \\
\text { inhabitant [thous. } \\
\text { EUR] }\end{array}$ \\
\hline Latvia & 6828.8 & 1696.4 & 24.8 & 26.27 & 865.53 \\
\hline Lithuania & 7791.6 & 1687.1 & 21.7 & 25.84 & 587.45 \\
\hline Poland & 96153.5 & 30040.5 & 31.2 & 96.07 & 792.62 \\
\hline
\end{tabular}

Source: author's calculations based on data of MF of Latvia and Lithuania and MIED of Poland

Basing on author's calculations, the share of transport infrastructure funding among all EU co-financed projects was similar in all countries, although in Poland it was the highest $(31.2 \%)$ and in Lithuania the lowest (21.7\%). This outcome is close to the data published in Breakdown of EU Structural Funds by Theme and Member State for the programming period 2007-2013 (EC, 2018), where $37 \%$ share of transport projects for Poland (the highest share among all EU countries), $23 \%$ for Lithuania and $25 \%$ for Latvia were indicated.

\section{The types and structure of implemented projects}

The number and value of different types of projects supporting transport infrastructure were presented in Tab. 2. In two of the three analysed countries, the amount of projects developing the Trans-European Transport Network (TEN-T) was the highest. The aim of developing the TEN-T network is to ensure territorial cohesion of the $\mathrm{EU}$ and to improve the free movement of people and 
goods (Adamiec, 2012). An efficiently functioning transport system within the Union is to contribute to the improvement of the operation of the internal market, stimulate the region's economic growth and increase the competitiveness of individual Member States and the entire EU on a global scale. The investments in TEN-T network in all countries included mainly reconstruction of national roads and reconstruction of railways. Also intermodal container and railway terminals were developed, mainly in Poland, where the total value of TEN-T projects amounted about 10 billion EUR due to construction of new motorways (A1, A4) and new express roads (i.a. parts of S3, S5, S7, S8, S69).

Number and value of different types of projects supporting transport infrastructure (co-financed by EU funds in perspective 2007-2013)

\begin{tabular}{|l|c|c|c|c|c|c|}
\hline \multirow{2}{*}{ Types of projects } & \multicolumn{2}{|c|}{ Latvia } & \multicolumn{2}{c|}{ Lithuania } & \multicolumn{2}{c|}{ Poland } \\
\cline { 2 - 7 } & $\begin{array}{c}\text { number } \\
\text { of } \\
\text { projects }\end{array}$ & $\begin{array}{c}\text { value of } \\
\text { projects [m. } \\
\text { EUR] }\end{array}$ & $\begin{array}{c}\text { number } \\
\text { of } \\
\text { projects }\end{array}$ & $\begin{array}{c}\text { value of } \\
\text { projects [m. } \\
\text { EUR] }\end{array}$ & $\begin{array}{c}\text { number } \\
\text { of } \\
\text { projects }\end{array}$ & $\begin{array}{c}\text { value of } \\
\text { projects [m. } \\
\text { EUR] }\end{array}$ \\
\hline the TEN-T routes & 29 & 411.8 & 23 & 479.6 & 28 & 10061.0 \\
\hline rail infrastructure & 9 & 364.3 & 28 & 528.2 & 146 & 6095.4 \\
\hline $\begin{array}{l}\text { sea transport } \\
\text { infrastructure }\end{array}$ & 10 & 332.2 & 8 & 56.3 & 45 & 776.1 \\
\hline $\begin{array}{l}\text { regional and local } \\
\text { roads }\end{array}$ & 147 & 199.4 & 240 & 277.8 & 2544 & 5744.9 \\
\hline $\begin{array}{l}\text { national roads } \\
\text { and highways }\end{array}$ & 50 & 191.3 & 19 & 280.7 & 123 & 5012.3 \\
\hline airports & 2 & 121.7 & 18 & 57.9 & 83 & 967.0 \\
\hline city transport & 4 & 75.9 & 0 & 0.0 & 99 & 834.4 \\
\hline $\begin{array}{l}\text { inland water } \\
\text { transport } \\
\text { infrastructure }\end{array}$ & & 0.0 & 4 & 6.6 & 16 & 95.5 \\
\hline $\begin{array}{l}\text { multimodal and } \\
\text { other transport }\end{array}$ & 0 & 0.0 & 0 & 0.0 & 46 & 454.0 \\
\hline
\end{tabular}

Source: author's calculations based on data of MF of Latvia and Lithuania and MIED of Poland

The second place in total value in Poland and Latvia was taken by rail infrastructure projects. In Poland, one of them was modernization of the E 75 Rail Baltica line running from Warsaw through Bialystok to the border with Lithuania (section Warsaw Rembertow - Sadowne). In Lithuania, in the Rail Baltica corridor contracts for reconstruction of the existing railway line Marijampole-Kazlu Ruda-Kaunas were conducted. This project allowed to reconstruct the existing $1520 \mathrm{~mm}$ wide line and build new tracks which comply with the European track standard (1435 mm wide), which allowed to run the first direct train from Bialystok to Kaunas in June 2016. In 2017, further works financed by the Connecting Europe Facility - CEF on next section between Sadowne and Bialystok started. As we can see, the mentioned railway projects were complementary and they will finally allow railway communication between Poland and Lithuania through Bialystok, Elk, Olecko and Suwalki (Graff, M., 2017). Also in Lithuania, Latvia and Estonia conception works on Rail Baltica go on, the whole route from Kaunas to Tallinn is expected to be completed by the year 2025 (AECOM, 2011).

In Lithuania and Poland, national, regional and local roads and highways reconstruction projects took the third place; taking into account the value of projects and considering the number of projects this category was the most numerous in each country. In Latvia, important share of funds was spent on sea transport infrastructure under the measure development of large port infrastructure under the "motorways of the sea". 


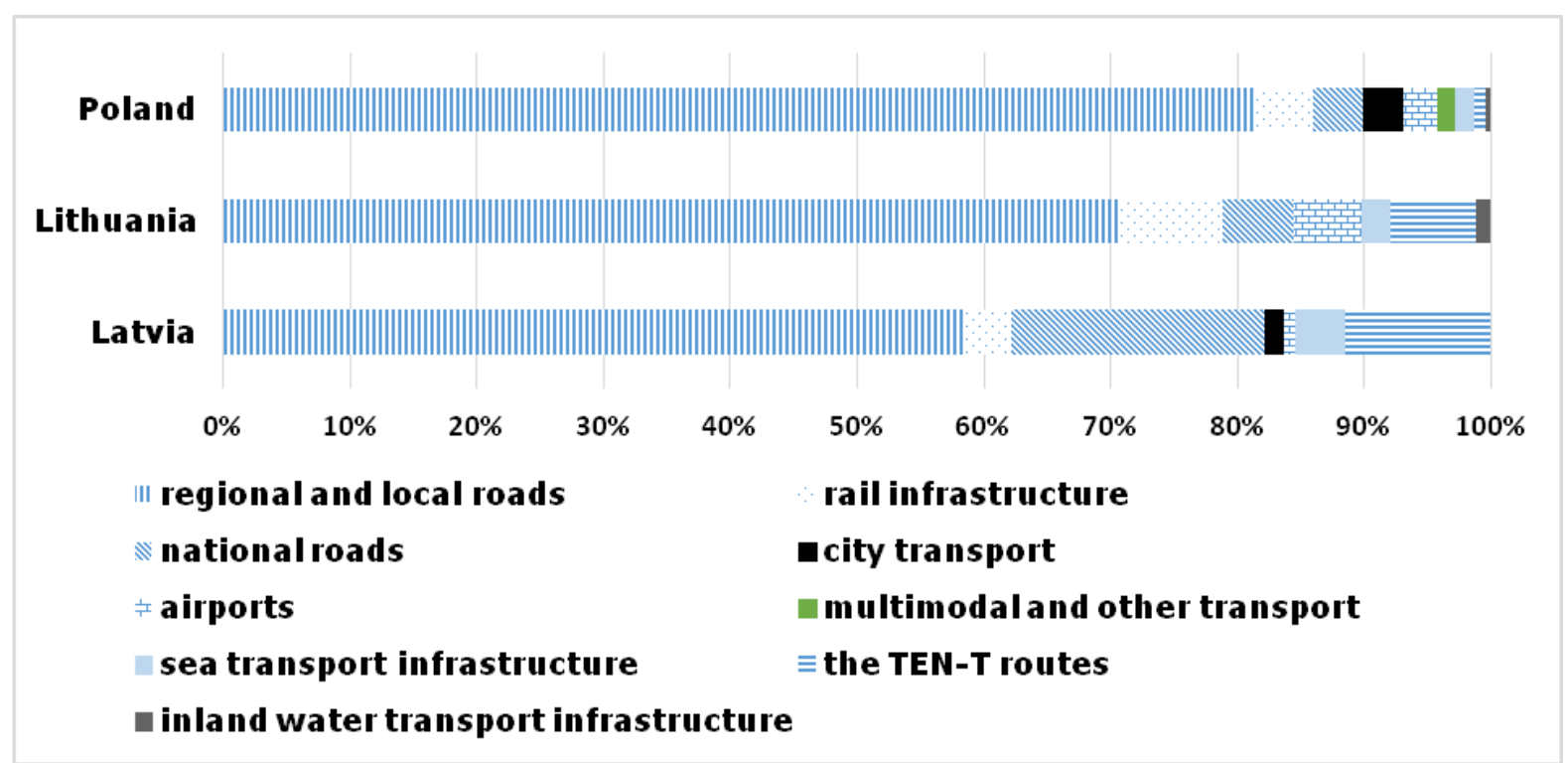

Source: author's calculations based on data of MF of Latvia and Lithuania and MIED of Poland

Fig. 1. The quantitative structure of implemented transport infrastructure projects co-financed by EU funds in perspective 2007-2013

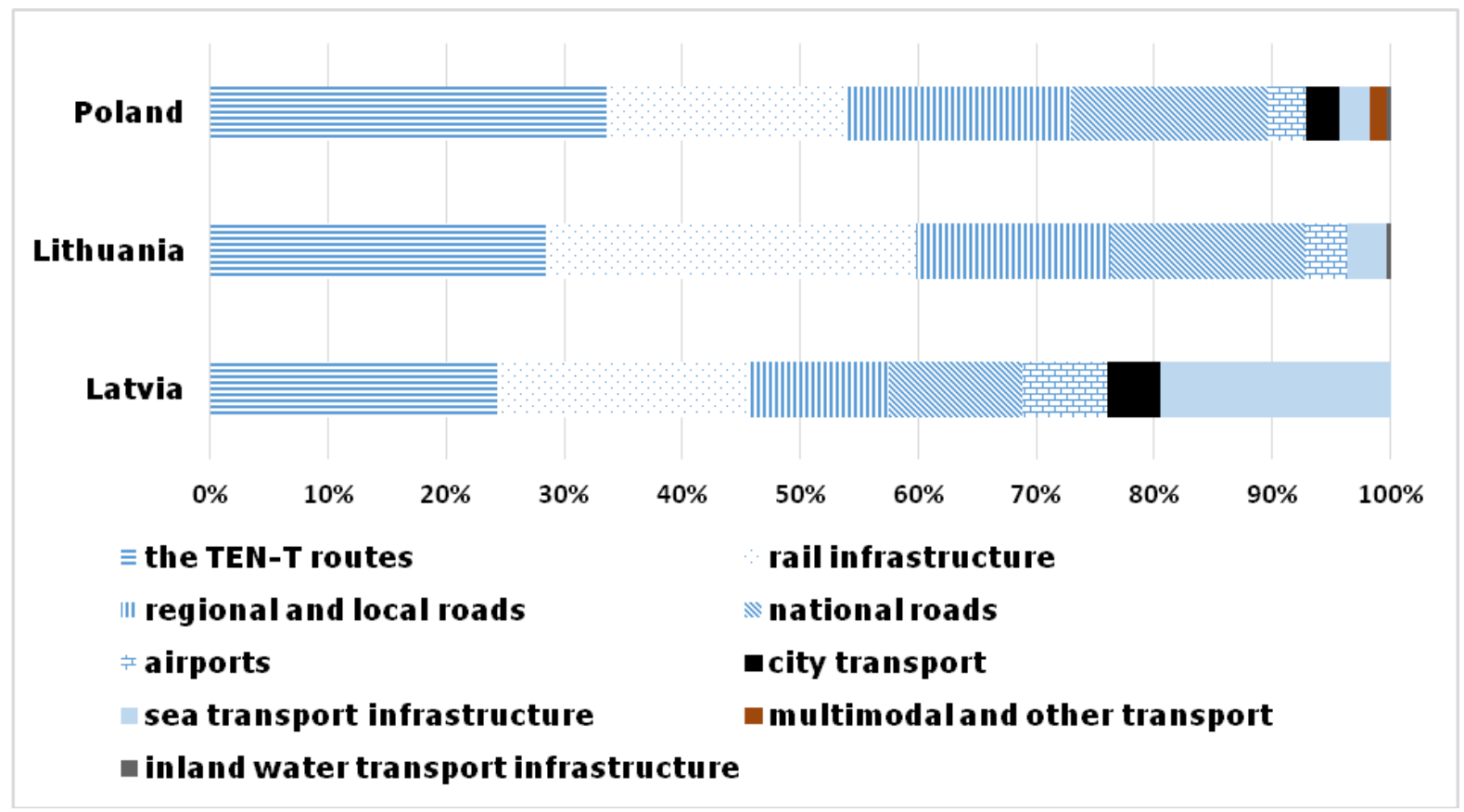

Source: author's calculations based on data of MF of Latvia and Lithuania and MIED of Poland

Fig. 2. The structure of value of implemented transport infrastructure projects co-financed by EU funds in perspective 2007-2013

Important investments in ports in Ventspils and Liepaja and in Freeport of Riga allowed to comply water quays with the best international port practices, helped development of terminals and necessary road and rail access to the port areas (ROP, 2015). Also ports in Klaipeda, Gdansk, Gdynia, Szczecin and Elblag were beneficiaries of EU funds investing in adapting infrastructure to serve increasingly larger and more modern units (Grzybowski, M., 2014). Expansion and modernization of airport infrastructure was carried out in nearly all airports in the three countries: Liepaja and Riga in Latvia, Vilnius, Kaunas and Palanga in Lithuania and in every Polish airport, except Radom. 
Other types of projects consisted in investments in inland water transport infrastructure and multimodal and other transport infrastructure, also city transport. More about support for the urban public transport from the EU funds can be found in the paper by Wojewodzka-Wiewiorska, A. (2014).

The differences in structure of projects were presented in Fig. 1 and Fig. 2. The highest number of projects in all countries concerned regional and local roads (58-81\%). The structure of projects' value was far more balanced, as investments in TEN-T routes, railway infrastructure, national, regional roads had about $13-33 \%$ share. This leads to the conclusion that the most expensive investments with most extensive range were made on the TEN-T network and railroads.

\section{Beneficiaries of infrastructure projects}

The structure of beneficiaries was analysed only for Lithuania and Poland because of data availability.

Beneficiaries and values of EU co-financed projects supporting transport

Table 3 infrastructure in Lithuania (financial perspective 2007-2013)

\begin{tabular}{|l|l|c|}
\hline \multicolumn{1}{|c|}{ Beneficiary (number of beneficiaries) } & \multicolumn{1}{c|}{ types of projects } & $\begin{array}{c}\text { total value of projects } \\
\text { [m. EUR] }\end{array}$ \\
\hline Lithuanian Road Administration & $\begin{array}{l}\text { the TEN-T routes, } \\
\text { national roads and highways }\end{array}$ & 760.3 \\
\hline Lithuanian Railways & rail infrastructure & 528.2 \\
\hline Municipalities (60) & regional and local roads & 277.8 \\
\hline Lithuanian Airports & airports & 57.9 \\
\hline Klaipeda Maritime Office & sea transport infrastructure & 56.3 \\
\hline Directorate of inland waterways & inland water transport infrastructure & 6.6 \\
\hline
\end{tabular}

Source: author's calculations based on data of Ministry of Finance of the Republic of Lithuania

In Lithuania, all infrastructure investments were highly institutionally concentrated - besides 60 municipalities (rajono or miesto savivaldybes administracija) only 5 state-owned entities or companies ran infrastructure projects: Lithuanian Road Administration, Lithuanian Railways, Lithuanian Airports, Klaipeda Maritime Office and Directorate of inland waterways.

In Poland, the situation was very different. As one can see in Tab. 4, in Poland the responsibility for transport infrastructure is spread over many entities of various types. Due to the larger surface area of the country 1260 local administrations of municipalities, counties and regions were involved in infrastructure projects. They built and reconstructed not only local and regional but also national roads, which is a result of road management system in Poland - national roads within cities with poviat rights are managed by the city administration. Interestingly, also municipalities were involved in railway infrastructure modernisation projects. Regional administration purchased and modernized many passenger trains for regional railways. State organizational units and state legal entities as General Directorate for National Roads and Motorways (GDDKiA), Police, State Fire Service were involved in the construction of TEN-T routes, national roads and highways, but also in projects to improve safety and rescue services. Maritime Offices, Regional Water Management Authorities (RZGW), SAR implemented sea and inland transport infrastructure projects. Among enterprises Polish State Railways (PKP-PLK, PKP Intercity) and 6 other railway companies developed their rolling stock, among others by purchase and modernization of electric traction units. Polish Air Navigation Services Agency (PAZP) and airport companies were involved in 
development of the infrastructure of the state air traffic management authority and improvement of security and protection of airports and development of their infrastructure.

Total values and types of EU co-financed projects supporting transport infrastructure in Poland by beneficiaries [million EUR]

\begin{tabular}{|c|c|c|c|c|c|}
\hline $\begin{array}{l}\text { Types } \\
\text { of } \\
\text { benefici } \\
\text { aries }\end{array}$ & $\begin{array}{c}\text { state organizational units and } \\
\text { legal entities }\end{array}$ & $\begin{array}{l}\text { local and } \\
\text { regional } \\
\text { governments }\end{array}$ & enterprises & $\begin{array}{c}\text { government } \\
\text { administration } \\
\text { bodies }\end{array}$ & $\begin{array}{l}\text { ot } \\
\text { he } \\
r \\
\text { en } \\
\text { titi } \\
\text { es }\end{array}$ \\
\hline $\begin{array}{l}\begin{array}{r}\text { Exampl } \\
\text { es of } \\
\text { benefici } \\
\text { aries }\end{array} \\
\begin{array}{l}\text { Types } \\
\text { of } \\
\text { project } \\
\text { s }\end{array}\end{array}$ & $\begin{array}{c}\text { General Directorate for } \\
\text { National Roads and Motorways, } \\
\text { Maritime Offices, Regional } \\
\text { Water Management } \\
\text { Authorities, SAR, Police, State } \\
\text { Fire Service }\end{array}$ & $\begin{array}{c}1260 \\
\text { administratio } \\
n s \text { of } \\
\text { municipalitie } \\
\text { s, counties } \\
\text { and regions }\end{array}$ & $\begin{array}{c}\text { Railway } \\
\text { companies, } \\
\text { airport } \\
\text { companies, } \\
\text { municipal } \\
\text { transport } \\
\text { companies }\end{array}$ & $\begin{array}{c}\text { Divisions of } \\
\text { General } \\
\text { Directorate for } \\
\text { National Roads } \\
\text { and Motorways, } \\
\text { ministries }\end{array}$ & $\begin{array}{l}\text { In } \\
\text { sti } \\
\text { tut } \\
\text { es }\end{array}$ \\
\hline $\begin{array}{l}\text { the } \\
\text { TEN-T } \\
\text { routes }\end{array}$ & 9925.0 & 0.0 & 152.9 & 136.0 & 0.0 \\
\hline $\begin{array}{l}\text { rail } \\
\text { infrastr } \\
\text { ucture }\end{array}$ & 0.0 & 452.7 & 5642.7 & 0.0 & 0.0 \\
\hline $\begin{array}{l}\text { sea } \\
\text { transpo } \\
\text { rt } \\
\text { infrastr } \\
\text { ucture }\end{array}$ & 198.4 & 376.2 & 191.5 & 10.1 & 0.0 \\
\hline $\begin{array}{l}\text { regiona } \\
\text { I and } \\
\text { local } \\
\text { roads }\end{array}$ & 2.9 & 5724.3 & 0.0 & 7.1 & $\begin{array}{r}10 . \\
6\end{array}$ \\
\hline $\begin{array}{l}\text { nationa } \\
\text { I roads } \\
\text { and } \\
\text { highwa } \\
\text { ys }\end{array}$ & 2790.4 & 1634.8 & 0.0 & 557.3 & $\begin{array}{r}29 . \\
6\end{array}$ \\
\hline airports & 82.1 & 2.3 & 879.7 & 2.9 & 0.0 \\
\hline $\begin{array}{l}\text { city, } \\
\text { multim } \\
\text { odal } \\
\text { and } \\
\text { other } \\
\text { transpo } \\
\text { rt }\end{array}$ & 0.8 & 898.0 & 236.6 & 0.0 & 0.0 \\
\hline $\begin{array}{l}\text { inland } \\
\text { water } \\
\text { transpo } \\
\text { rt } \\
\text { infrastr } \\
\text { ucture }\end{array}$ & 91.9 & 3.5 & 0.0 & 0.0 & 0.0 \\
\hline Total & 13091.4 & 9092.0 & 7103.4 & 713.5 & $\begin{array}{r}40 \\
.2\end{array}$ \\
\hline
\end{tabular}

Source: author's calculations based on data of Ministry of Investment and Economic Development of Poland 


\section{Conclusions, proposals, recommendations}

The paper compared the development of transport infrastructure with support of structural funds in Latvia, Lithuania and Poland. Projects connected with transport infrastructure development were classified and the share of infrastructure projects in all EU funding was calculated. The main conclusions are stated below.

1) Poland had the highest value of infrastructure projects from the analysed countries ( 30 billion EUR) and the highest share of transport infrastructure in total structural funding among all EU countries.

2) In Latvia and Lithuania, the total values of all transport infrastructure supporting projects were very close to each other (1.7 billion EUR).

3) In relation to the population, Latvia invested most (865 thous. EUR per inhabitant), Poland took second place and Lithuania the third with 587 thousand euro per capita.

4) In all three countries, most funds were spent on Trans-European Transport Network (TEN-T), reconstruction of national, regional and local roads and reconstruction of railways.

5) In Latvia, also sea port infrastructure in Riga and Liepaja was developed with high aid of EU funds.

6) The most expensive investments with most extensive range were made on the TEN-T network and railroads.

7) In Lithuania, all infrastructure investments were highly institutionally concentrated, while in Poland due to the larger surface area of the country and different organization the number of beneficiaries was much higher.

8) In Poland, the responsibility for transport infrastructure is spread over many entities of various types, as a result coordination between their actions and investments is needed.

9) Some projects were complementary and in future they will allow to connect the Baltic States with Western Europe (i.a. Rail Baltica project).

10) Polish EU funds monitoring system for the period 2007-2013 contains some errors in classification of entities, thus before analysing the data, they must be checked and ordered.

As one can see, the support of EU structural funds for transport infrastructure development in Latvia, Lithuania and Poland was very important and allowed to increase the spatial cohesion of the analysed region. Further studies could be focused on the analysis of the effects of the infrastructure for improvement of safety, shorten of travel time and increasing the level of economic development.

\section{Bibliography}

1. Adamiec, J. (2012). Transeuropejskie sieci transportowe (TEN-T). Studia BAS Nr 4(32). pp. 63-78.

2. Bachtler, J., Turok I. (eds.). (2013), The Coherence Of EU Regional Policy: Contrasting Perspectives On The Structural Funds. Routledge. London \& New York, p. 441.

3. Breakdown Of The Available Funds By Theme For 2007-2013, Retrieved: https://cohesiondata.ec.europa.eu/Country-Level/Breakdown-Of-The-Available-Funds-By-Theme-For2007/w597-agi6/data. Access: 10.01.2018.

4. Commission Regulation (EC) No 851/2006 of 9 June 2006 Specifying The Items To Be Included Under The Various Headings In The Forms Of Accounts Shown In Annex I To Council Regulation (EEC). Retrieved: http://eur-lex.europa.eu/legal-content/EN/TXT/HTML/?uri=CELEX:32006R0851\&from=PL. Access: 05.02.2018.

5. Graff, M. (2017). Railway Communication Between Poland And Lithuania (Komunikacja kolejowa pomiedzy Polska i Litwa). Technika Transportu Szynowego 6/2017, pp. 45-52.

6. Grzybowski, M., (2014). Investments In The Eastern Baltic Sea Ports. Case Studies (Inwestycje w portach morskich wschodniego Baltyku. Studia przypadkow). Logistyka 6/2014. pp. 689-698. 
7. The Russian-Island Infrastructure Development Project Has Been Put Into Operation (Krievu salas infrastrukturas attistibas projekts ir nodots ekspluatacija). Retrieved: http://rop. Iv/lv/jaunumi/5396-krievusalas-infrastrukturas-attistibas-projekts-ir-nodots-ekspluatacija.html. Access: 18.01.2018.

8. Ministry of Finance of the Republic of Lithuania, Database Of EU-Cofinanced Projects In Lithuania. Retrieved: http://www.esparama.It Access: 17.12.2017.

9. Ministry of Investment and Economic Development of the Republic Poland, Database Of EU-Cofinanced Projects In Poland. Retrieved: http://funduszeeuropejskie.2007-2013.gov.pl Access: 10.01.2018.

10. Ministry of Finance of the Republic of Latvia, Database Of EU-Cofinanced Projects In Latvia. Retrieved: http://www.esfondi.lv Access: 18.12.2017.

11. Pereira, A. M., Andraz, J. M., (2005). Public Investment In Transportation Infrastructures And Economic Performance In Portugal. Review of Development Economics, Wiley Online Library retrieved: http://sapientia.ualg.pt/bitstream/10400.1/4709/3/Public Investment in Transportation Infrastructures and Economic Performance in Portugal.pdf Access: 05.02.2018

12. Rail Baltica Final Report Executive Summary. (2011). AECOM Transportation. p. 29.

13. Regulation (EU) No 1315/2013 Of The European Parliament And Of The Council Of 11 December 2013 On Union Guidelines For The Development Of The Trans-European Transport Network And Repealing Decision No 661/2010/EU Text With EEA Relevance. Retrieved: http://eur-lex.europa.eu/legalcontent/EN/ALL/?uri=CELEX:32013R1315. Access: 18.01.2018.

14. Wojewodzka-Wiewiorska, A. (2014). Support For Public Urban Transport From EU Funds 2007-2013 In Poland (Wsparcie publicznego transportu miejskiego z funduszy unijnych 2007-2013 w Polsce). Logistyka 4/2014. pp. 3784-3792. 